\title{
Experimental Study of the Possible Protective Effect of Alpha-Lipoic Acid on Paracetamol induced Oxidative Stress and Hepatic Toxicity in albino rats
}

\author{
Walaa A. Allam', Sara E. Kasem ${ }^{1}$, Sheren F. Mahmoud ${ }^{2}$, Amany A.Abdallah ${ }^{3}$, Maha A. Hilal ${ }^{1}$ \\ ${ }^{1}$ Forensic Medicine and Clinical Toxicology Department, Faculty of Medicine, Sohag University Sohag, Egypt. \\ ${ }^{2}$ Pathology Department, Faculty of Medicine, Sohag University Sohag, Egypt \\ ${ }^{3}$ Clinical Pathology Department, Faculty of Medicine, Sohag University Sohag, Egypt
}

\begin{abstract}
Background: Paracetamol, is the most widely used over-the-counter analgesic and antipyretic medication in the world, which has minimal adverse effects at therapeutic dosages. But in high doses causes hepatic damage and oxidative stress. Objectives: The current study was designed to investigate paracetamol toxic effects upon the liver and oxidative stress after repeated oral dose and evaluate possible protective effect of alpha lipoic acid when co-administered with and after paracetamol. Methods: forty eight white albino rats were divided equally into four groups. Each group was subdivided into two sub groups A \& B. Group I received gum acacia suspension. Group II received Alpha lipoic acid $(50 \mathrm{mg} / \mathrm{kg})$ orally. Group III received paracetamol ( $1 \mathrm{gm} / \mathrm{kg}$ orally) for 4 weeks. Group IV received paracetamol and alpha lipoic acid at the same doses. Sub groups A were euthanized after 4 weeks, while sub groups B were euthanized after 8 weeks. Blood was collected for evaluation of liver functions and oxidative stress marker. The livers were preserved for histopathological examinations. Results: The study proved that repeated administration of paracetamol induced disturbed liver functions and oxidative stress. But this toxic effects decline markedly when alpha lipoic acid (ALA) was coadministered with paracetamol. And more improvement occurs when ALA was administered for another 4 weeks after stoppage of paracetamol. Conclusions: The present study concluded that repeated paracetamol administration has hepatotoxic and oxidative stress effect and alpha lipoic acid has a protective effect against such harmful effects especially when ALA was administered for another 4 weeks after stoppage of paracetamol.
\end{abstract}

Key words Paracetamol; Hepatotoxicity, Oxidative stress, Alpha lipoic acid

\section{Introduction}

$\mathrm{P}$ aracetamol is used as analgesic and antipyretic drug in a wide manner; it is safe if used at the recommended dosage (Kanno et al., 2006).

$\mathrm{N}$-acetyl-p-aminophenol (APAP) is the chemical name of paracetamol (Swierkosz et al., 2002).

Paracetamol is metabolized mostly in the liver by glucuronidation, sulfation, oxidation and hydroxylation with elimination of unconjugated paracetamol in the urine (McGill and Jaeschke, 2013).

The metabolites of paracetamol excreted in the urine within twenty four hours (Ji et sal., 2012).

Paracetamol oxidation occurs by a CYP 450 oxidase enzyme to form N-acetyl-p-benzoquinone imine (NAPQI), which is rapidly conjugated with glutathione intracellular to form 3-glutathione-S-ylparacetamol then it is eliminated in urine or bile with lesser extent (Gelotte et al., 2007).

NAPQI causes hepatotoxicity after acute overdose of paracetamol due to exhaustion of glutathione stores (Hodgman and Garrard, 2012).

In toxicity, NAPQI which is not undergo detoxification bind to cysteine groups on the proteins forming what is called paracetamol-protein adducts in hepatic tissues. Increase levels of adducts results in hepatotoxicity (James et al., 2013).

Other mechanisms of paracetamol toxicity consist of development of toxic free radicals, as peroxynitrite, from the reaction of nitric oxide and superoxide, consequently forming nitro-tyrosine adducts inside the mitochondria leading to interruption of adenosine tri phosphate (ATP) synthesis (Jaeschke et al., 2012).

Chronic toxicity is a distinctive clinical condition involving multiple ingestions of paracetamol in a period more than 8 hours leading to a cumulative dosage of greater than $4 \mathrm{~g} \backslash 24$ hours (Daly et al., 2004).

Alpha lipoic acid (ALA) is considered a natural antioxidant, stated as a "universal antioxidant" (Koufaki and Detsi, 2010). ALA is made within animals and plants; however its synthesis is very low in humans (Wada et al., 1997).

ALA and its reduced form, which is dihydrolipoic acid, are potent antioxidants behave as a scavenger for both reactive nitrogen species (RNS) \& reactive oxygen species (ROS) (Karaarslan et al., 2013). 


\section{Aim of the Study}

The present study aims to evaluate the protective effects of ALA on liver toxicity and the oxidative stress induced by paracetamol.

\section{Materials and Methods}

A- Animals:

The present study was set on 48 white, male albino rats weighing (180 $\pm 40 \mathrm{gm})$. They were supplied by the animal Facility Centre of Faculty of Medicine, Assiut University. Animals were housed in the animal house, Faculty of Medicine, Sohag University, in metal cages under ambient temperature, $21 \pm 3^{\circ} \mathrm{C}$. They were adapted to laboratory condition for 7 days before the beginning of the treatment protocol. The study was performed in the period from October / 2017December/2017.

The ethics and husbandry conditions of animal research were considered according to the protocol of care and use of laboratory animals which is approved by the ethical committee of Faculty of Medicine, Sohag University. Animals were fed with standard pellet food and water. The protocol was approved by the ethical committee of Faculty of Medicine, Sohag University.

B- Material:

Chemicals

- Kits of Alanine amino-transferase (ALT) \& Aspartate amino-transferase (AST) and total protein were purchased from Beckman Coulter Inc. Company.

- Kits of catalase were purchased from Bio diagnostic company.

- Paracetamol, GlaxoSmithKline (abimol) from a commercial pharmacy.

- Alpha lipoic acid, Eva pharma (Thiotacid 300) from a commercial pharmacy.

- Gum acacia from commercial market.

- Hematoxylin and eosin stains purchased from ALPHACHEMIKA.

Apparatuses

a) Beckman Coulter AU480 Clinical Chemistry System: Fully automated, analytical principles: spectrophotometry and potentiometry. Present in Clinical Pathology Department-Sohag University Hospitals.

b) UV 2300 spectrophotometer (USA): Has 190-1100 $\mathrm{nm}$ wave length range of and also has a programmable 5-turret sample compartment. Present in Faculty of Science, Sohag University.

c) Centrifuge, Hettich Zentifugen - model (EBA20), 4000 revolutions per minute (rpm).

d) Water deionizer: Human corporation - model (human power one).

e) Micropipettes: HTL-model: OP1000, OP100, serial micropipette.

f) Olympus CX 41 RF Light microscopy. At Pathology Department - Faculty of Medicine - Sohag University.

C- Methods: Animals groups

Animals were divided in a random manner into 4 groups, 12 animals each; each group was subdivided into 2 sub-groups A, B.
Group I (Gum acacia group): Gum acacia orally administered with a dosage of $2 \mathrm{ml} /$ day of $2 \%$ suspension (Abdel-Zaher et al., 2008). Group IA was sacrificed after 4 weeks \& Group IB was sacrificed after 8 weeks.

Group II (ALA group): Alpha lipoic acid (ALA) was orally administered (50 mg/kg/day) (Pradhan et al., 2016) suspended in $2 \%$ gum acacia. Group IIA was sacrificed after 4 weeks \& Group IIB was sacrificed after 8 weeks.

Group III: Paracetamol was orally administered (1g/kg /day) (Kiran et al., 2012 and Pachaiyappan et al., 2014) suspended in $2 \%$ gum acacia for 4 weeks. LD50 of oral paracetamol is $3-4.5 \mathrm{gm} / \mathrm{kg}$ in rats (Boyd and Bereczky, 1966). The administered dose is about $1 \backslash$ 4 of LD50

Group IIIA (Paracetamol only group) was sacrificed after 4 weeks \& Group IIIB (Paracetamol withdrawal group) was left without treatment for another 4weeks then sacrificed.

Group IV: Group IVA (Paracetamol and ALA group) paracetamol was orally administered at a dosage of ( $1 \mathrm{~g} / \mathrm{kg} /$ day) and ALA (50 mg / $\mathrm{kg} /$ day) for 4 weeks then sacrificed. Group IVB (Treatment group) Paracetamol was orally administered at a dosage of $1 \mathrm{~g} /$ $\mathrm{kg} /$ day and ALA at a dosage of $50 \mathrm{mg} / \mathrm{kg}$ /day orally for 4 weeks then treated with ALA only (50 mg $/ \mathrm{kg} /$ day) for another 4 weeks then sacrificed.

D- Collection of samples:

i- Blood samples:

Rats were anesthetized using light ether inhalation. $3 \mathrm{ml}$ of blood were obtained from each animal from cervical blood vessels during slaughtering into clean dry plain tubes for assessment of liver functions (ALT, AST and total protein) and serum catalase.

The serum was obtained after sampling by centrifugation (4000 rpm for 10 minutes), then divided into two parts. $1^{\text {st }}$ one transferred into sterile screw capped polypropylene tubes and analyzed for liver function. The remaining sera were placed in sterile polypropylene tubes which is screw capped and it is stored at $-70^{\circ} \mathrm{C}$ until analysis of serum catalase.

ii- Tissue samples

Autopsy was performed for all groups of animal. Liver samples fixed in $10 \%$ formaldehyde and paraffin embedding and cut at $5 \mu \mathrm{m}$ sections, (H\&E) stain was used. The sections were examined by the light microscope then it was photographed.

Statistical analysis:

Statistical procedures were computed using Statistical Program for Social Science (SPSS), V.16.0 computer software. SPSS inc. Chicago, USA. All data were presented as mean \pm SD and compared to each other by using Student's t-test and one way ANOVA test. $\mathrm{P}$ value $<0.05$ was referred as significant. The data was presented in the form of graphs and tables.

\section{Results}

I- Biochemical results:

I.1.Results of liver functions tests:

As regard ALT, Non-significant statistical difference in the mean values of serum ALT between the following groups: IA (50 IU/1), IB (51.17 IU/1), IIA 
(49.33 IU/1) and IIB (50.33 IU/l) where $\mathrm{p}$ value was 0.854 . As shown in table (1) \& graph (1).

There was a significant statistical increase in the mean values of serum ALT in group IIIA (80.2 IU/1) as compared to group IA (50 IU/1) and in group IVA (60 IU/l) as compared to group IIA (49.33 IU/1) where $p$ values were $<0.001,0.002$ respectively. As shown in table (1) \& graph (1).

Also, a significant statistical increase in the mean values of serum ALT in group IIIB (69.2 IU/l) as compared to group IB 51.17 IU/1 ( $p$ value $<0.001$ ), while there was no significant statistical difference in group IVB (50 IU/l) as compared to group IIB 50.33 IU/1 ( $p$ value 0.669 ) (table (1) \& graph (1)).

There was a significant statistical decrease in the mean values of serum ALT in group IIIB (69.2 IU/l) as compared to group IIIA [(80.2 IU/1) (p value $0.001)]$, and in group IVB (50 IU/1) as compared to group IVA (60 IU/l) where $p$ value was 0.004 . As shown in table (1) \& table (4)

There was a significant statistical decrease in the mean values of serum ALT in group IVA (60 IU/1) as compared to group IIIA (80.2 IU/l) where $p$ value was $<0.001$, and in group IVB (50 IU/1) as compared to group IIIB (69.2 IU/l) where p value was $<0.001$. As shown in table (1) \& table (4).

As regard AST, there was non-significant statistical difference in mean values of serum AST between the groups IA (156 IU/1), IB (155 IU/1), IIA $(150 \mathrm{IU} / \mathrm{l})$ and IIB (152 IU/1) where $\mathrm{p}$ value was 0.22 as shown in table (2) \& graph (2).

There was a significant statistical increase in the mean values of AST serum level in group IIIA (220 IU/l) as compared to group IA (156 IU/l) and in group IVA (165 IU/1) as compared to group IIA (150 IU/l) where $\mathrm{p}$ values were $<0.001,0.031$ respectively. As shown in table (2) \& graph (2).

Also, there was a significant statistical increase in the mean values of AST serum level in group IIIB (180 IU/l) as compared to group IB $155 \mathrm{IU} / 1$ ( $\mathrm{p}$ value < $0.001)$, while there was no significant statistical difference in group IVB (156 IU/l) as compared to group IIB 152 IU/1 (p value 0.756). As shown in table (2) \& graph (2).

There was a significant statistical decrease in the mean values of serum AST in group IIIB (180 IU/1) as compared to group IIIA [(220 IU/l) (p value < $0.001)$, and in group IVB (156 IU/l) as compared to group IVA (165 IU/1) where $\mathrm{p}$ value was 0.031 . As shown in table (2) \& table (4).

There was a significant statistical decrease in the mean values of serum AST in group IVA (165 IU/1) as compared to group IIIA (220 IU/l) where $p$ value was $<0.001$, and in group IVB (156 IU/1) as compared to group IIIB $(180 \mathrm{IU} / \mathrm{l})$ where $\mathrm{p}$ value was $<0.001$. As shown in table (2) \& table (4).

As regard total protein, there was non significant statistical difference in the mean values of serum total protein between the groups IA $(6.60 \mathrm{gm}$ /dl), IB (6.53 gm/dl), IIA (6.48 gm /dl) and IIB (6.52 $\mathrm{gm} / \mathrm{dl}$ ) where $\mathrm{p}$ value was 0.90 . As shown in table (3) \& graph (3).
There was a significant statistical decrease in the mean values of serum total protein in group IIIA $(6.15 \mathrm{gm} / \mathrm{dl})$ as compared to group IA $6.60 \mathrm{gm} / \mathrm{dl}(\mathrm{p}$ value $<0.001)$. While, there was no significant statistical difference in group IVA $(6.5 \mathrm{gm} / \mathrm{dl})$ as compared to group IIA, $6.48 \mathrm{gm} / \mathrm{dl}$ ( $\mathrm{p}$ value 0.554 ). As shown in table (3) \& graph (3).

There was no significant statistical difference in the mean values of serum total protein in group IIIB (6.5 gm/dl) as compared to group IB (6.53 gm/dl) and in group IVB $(6.45 \mathrm{gm} / \mathrm{dl})$ as compared to group IIB $(6.52 \mathrm{gm} / \mathrm{dl})$ where $\mathrm{p}$ values were $0.811,0.714$ respectively. As shown in table (3) \& graph (3).

There was a significant statistical increase in the mean values of serum total protein in group IIIB (6.5 $\mathrm{gm} / \mathrm{dl}$ ) as compared to group IIIA, $6.15 \mathrm{gm} / \mathrm{dl}$ ( $\mathrm{p}$ value 0.001). While, there was no significant statistical difference in the mean values of serum total protein in group IVB (6.45 gm/dl) as compared to group IVA, 6.5 $\mathrm{gm} / \mathrm{dl}$ (p value 0.836 ) as shown in table (3) \& table (4).

There was a significant statistical increase in the mean values of serum total protein in group IVA (6.5 $\mathrm{gm} / \mathrm{dl}$ ) as compared to group IIIA, $6.15 \mathrm{gm} / \mathrm{dl}$ (p value 0.047). While, there was no significant statistical difference in the mean values of serum total protein in group IVB (6.45 gm/dl) as compared to group IIIB, 6.5 $\mathrm{gm} / \mathrm{dl}$ (p value 0.801 ) as shown in table (3) \& table (4). I.2.Results of oxidative stress marker (Catalase): there was no significant statistical difference in the mean values of serum catalase between groups IA (100.33 U/L), IB (101.67 U/L), IIA (99.17 U/L) and IIB (99.83 $\mathrm{U} / \mathrm{L}$ ) where $\mathrm{P}$ value was 0.954 . As shown in table (5) \& graph (4)

There was a significant statistical decrease in the mean values of serum catalase in group IIIA (53.67 $\mathrm{U} / \mathrm{L})$ as compared to group IA (100.33 U/L) and in group IVA $(70.17 \mathrm{U} / \mathrm{L})$ as compared to group IIA $(99.17 \mathrm{U} / \mathrm{L})$ where $\mathrm{p}$ values were $<0.001,<0.001$. As shown in table (5) \& graph (4).

Also, there was a significant statistical decrease in the mean values of serum catalase in group IIIB (65.33 U/L) as compared to group IB (101.67 U/L) where $\mathrm{p}$ value was $<0.001$, while there was nonsignificant statistical decrease in group IVB (91.33 $\mathrm{U} / \mathrm{L})$ as compared to group IIB $(99.83 \mathrm{U} / \mathrm{L})$ where $\mathrm{p}$ value was 0.068 as shown in table (5) \& graph (4)

There was a significant statistical increase in the mean values of serum catalase in group IIIB (65.33 $\mathrm{U} / \mathrm{L})$ as compared to group IIIA (53.67 U/L) where $\mathrm{p}$ value was 0.008 , and in group IVB $(91.33 \mathrm{U} / \mathrm{L})$ as compared to group IVA $(70.17 \mathrm{U} / \mathrm{L})$ where $\mathrm{p}$ value was 0.002 , as shown in table (5) \& table (6).

There was a significant statistical increase in the mean values of serum catalase in group IVA (70.17 $\mathrm{U} / \mathrm{L})$ as compared to group IIIA (53.67 U/L) where $\mathrm{p}$ value was 0.003 , and in group IVB $(91.33 \mathrm{U} / \mathrm{L})$ as compared to group IIIB $(65.33 \mathrm{U} / \mathrm{L})$ where $p$ value was $<0.001$, as shown in table (5) \& table (6).

II. Histopathological results of Liver in the study groups:

Group I: Haematoxylin and eosin (H\&E) examination of a section of a liver of group IA, IB 
showed a normal histological appearance of the hepatic architecture, normal central vein, blood sinusoids and the surrounding portal triads. The hepatocytes were within the normal structure. They are polygonal with pink cytoplasm and centrally located vesicular nuclei (figure 1).

Group II: H\&E examination of a section of a liver of group IIA, IIB showed normal histological appearance of hepatic architecture, normal central vein appearance, blood sinusoids and the surrounding portal triads. The hepatocytes were within normal histological appearance (figure 2).

Group IIIA: Histopathological examination of a section of a liver of group IIIA revealed marked dilatation and congestion of central veins and portal venules.

There was marked vacuolar degeneration of hepatocytes (hydropic swelling of hepatocytes with abundant pale cytoplasm, leads to lytic necrosis and replacement by inflammatory cells) (figure 3 ).

Group IIIB: Examination of H\&E stained slides from liver of group IIIB revealed moderate congestion and dilatation of central vein and the portal venules. There was moderate vacuolar degeneration of hepatocytes (figure 4).

Group IVA: Stained slides of section of liver of group IVA revealed moderate congestion and dilatation of central vein and the portal venules. Also, there was moderate vacuolar degeneration of hepatocytes (figure 5).

Group IVB: Microscopic examination of a section of a liver of group IVB revealed mild congestion and dilatation of central vein and the portal venules. Also, there was mild vacuolar degeneration of hepatocytes (figure 6)

Table (1): Statistical analysis ANOVA One Way test \& Student t- test of the ALT of the studied groups

\begin{tabular}{|c|c|c|}
\hline \multirow{2}{*}{ Groups } & Serum ALT (IU/I) & \multirow{2}{*}{ P-value } \\
\hline & Mean \pm SD & \\
\hline Group IA & $50 \pm 3.41$ & \multirow{4}{*}{$0.854^{*}$} \\
\hline Group IB & $51.17 \pm 4.88$ & \\
\hline Group IIA & $49.33 \pm 3.14$ & \\
\hline Group IIB & $50.33 \pm 2.94$ & \\
\hline Group IIIA & $80.2 \pm 2.86$ & $\begin{array}{l}\text { IIIA versus IA }^{* *} \\
<0.001^{* * *}\end{array}$ \\
\hline Group IIIB & $69.2 \pm 4.58$ & $\begin{array}{l}\text { IIIB versus IB } \\
\quad<0.001^{* * *}\end{array}$ \\
\hline Group IVA & $60 \pm 4.98$ & $\begin{array}{c}\text { IVA versus IIA }^{* *} \\
0.002^{* * *}\end{array}$ \\
\hline Group IVB & $50 \pm 4.29$ & 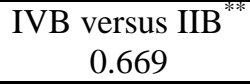 \\
\hline
\end{tabular}

Significant difference at $p$ value < 0.05, SD: standard deviation, *ANOVA test, **Student t- test, *** Statistically significant difference

Table (2): Statistical analysis ANOVA One Way test \& Student t- test of the AST of the studied groups

\begin{tabular}{|c|c|c|}
\hline \multirow{2}{*}{ Groups } & Serum AST (IU/l) & \multirow{2}{*}{ P-value } \\
\hline & Mean \pm SD & \\
\hline Group IA & $156 \pm 7.39$ & \multirow{4}{*}{$0.22^{*}$} \\
\hline Group IB & $155 \pm 7.08$ & \\
\hline Group IIA & $150 \pm 3.74$ & \\
\hline Group IIB & $152 \pm 6.10$ & \\
\hline Group IIIA & $220 \pm 15.4$ & $\begin{array}{l}\text { IIIA versus IA }^{* *} \\
\quad<0.001^{* * *}\end{array}$ \\
\hline Group IIIB & $180 \pm 8.13$ & $\begin{array}{l}\text { IIIB versus IB } \\
\quad<0.001^{* * *}\end{array}$ \\
\hline Group IVA & $165 \pm 4.07$ & $\begin{array}{c}\text { IVA versus IIA }^{* *} \\
0.031^{* * *}\end{array}$ \\
\hline Group IVB & $156 \pm 7.30$ & $\begin{array}{c}\text { IVB versus IIB }^{* *} \\
0.756\end{array}$ \\
\hline
\end{tabular}

Significant difference at $p$ value < 0.05, SD: standard deviation, *ANOVA test, ** t- test,

***Statistically significant difference 
Table (3): Statistical analysis ANOVA One Way test \& Student t- test of the total protein of the studied groups

\begin{tabular}{|c|c|c|}
\hline \multirow[b]{2}{*}{ Groups } & Serum total protein (gm/dl) & \multirow[b]{2}{*}{ P-value } \\
\hline & Mean \pm SD & \\
\hline Group IA & $6.60 \pm 0.18$ & \multirow{4}{*}{$0.90^{*}$} \\
\hline Group IB & $6.53 \pm 0.30$ & \\
\hline Group IIA & $6.48 \pm 0.29$ & \\
\hline Group IIB & $6.52 \pm 0.31$ & \\
\hline Group IIIA & $6.15 \pm 0.12$ & $\begin{array}{l}\text { IIIA versus IA }^{* *} \\
\quad<0.001^{* * *}\end{array}$ \\
\hline Group IIIB & $6.50 \pm 0.14$ & $\begin{array}{c}\text { IIIB versus IB }^{* *} \\
0.811\end{array}$ \\
\hline Group IVA & $6.50 \pm 0.36$ & $\begin{array}{c}\text { IVA versus IIA }^{* *} \\
0.554\end{array}$ \\
\hline Group IVB & $6.45 \pm 0.45$ & 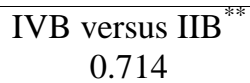 \\
\hline
\end{tabular}

Significant difference at p value <0.05, SD: standard deviation, *ANOVA test, ** Student t- test

$* * *$ Statistically significant difference

Table (4): The statistical difference of serum ALT, AST and total protein in the different study groups using Student t- test.

\begin{tabular}{|c|c|c|c|}
\hline \multirow{2}{*}{ Groups } & Serum ALT & Serum AST & Serum Total protein \\
\hline & ${ }^{*}$ P value & ${ }^{*}$ P value & ${ }^{*} P$ value \\
\hline IIIA Versus IIIB & $0.001^{* *}$ & $<0.001^{* *}$ & $0.001^{* *}$ \\
\hline IVA Versus IVB & $0.004^{* *}$ & $0.031^{* *}$ & 0.836 \\
\hline IIIA Versus IVA & $<0.001^{* *}$ & $<0.001^{* *}$ & $0.047^{* *}$ \\
\hline IIIB Versus IVB & $<0.001^{* *}$ & $<0.001^{* *}$ & 0.801 \\
\hline
\end{tabular}

* Significant difference at $p$ value $<0.05,{ }^{* *}$ Statistically significant difference

Table (5): Statistical analysis ANOVA One Way test \& Student t- test of the serum catalase of the studied groups

\begin{tabular}{|c|c|c|}
\hline \multirow[b]{2}{*}{ Groups } & Catalase (U/L) & \multirow[b]{2}{*}{ P-value } \\
\hline & Mean \pm SD & \\
\hline Group IA & $100.33 \pm 7.76$ & \multirow{4}{*}{$0.954^{*}$} \\
\hline Group IB & $101.67 \pm 8.16$ & \\
\hline Group IIA & $99.17 \pm 8.11$ & \\
\hline Group IIB & $99.83 \pm 7.47$ & \\
\hline Group IIIA & $53.67 \pm 6.35$ & $\begin{array}{l}\text { IIIA versus IA }^{* *} \\
\quad<0.001^{* * *}\end{array}$ \\
\hline Group IIIB & $65.33 \pm 5.85$ & $\begin{array}{l}\text { IIIB versus IB }^{* *} \\
\quad<0.001^{* * *}\end{array}$ \\
\hline Group IVA & $70.17 \pm 8.26$ & $\begin{array}{l}\text { IVA versus IIA }^{* *} \\
<0.001^{* * *}\end{array}$ \\
\hline Group IVB & $91.33 \pm 9.31$ & 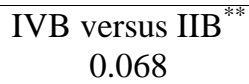 \\
\hline
\end{tabular}

Significant difference at p value <0.05, SD: standard deviation, *ANOVA test, ** Student t- test ***Statistically significant difference

Table (6): The statistical difference of catalase in the studied groups using Student t- test.

\begin{tabular}{|c|c|}
\hline \multirow{2}{*}{ Groups } & Catalase \\
\cline { 2 - 2 } & ${ }^{*}$ P value \\
\hline IIIA Versus IIIB & $\mathbf{0 . 0 0 8}{ }^{* *}$ \\
\hline IVA Versus IVB & $\mathbf{0 . 0 0 2 ^ { * * }}$ \\
\hline IIIA Versus IVA & $\mathbf{0 . 0 0 3 ^ { * * }}$ \\
\hline IIIB Versus IVB & $<\mathbf{0 . 0 0 1}$ \\
\hline
\end{tabular}

*Significant difference at $p$ value $<0.05,{ }^{* *}$ Statistically significant difference 


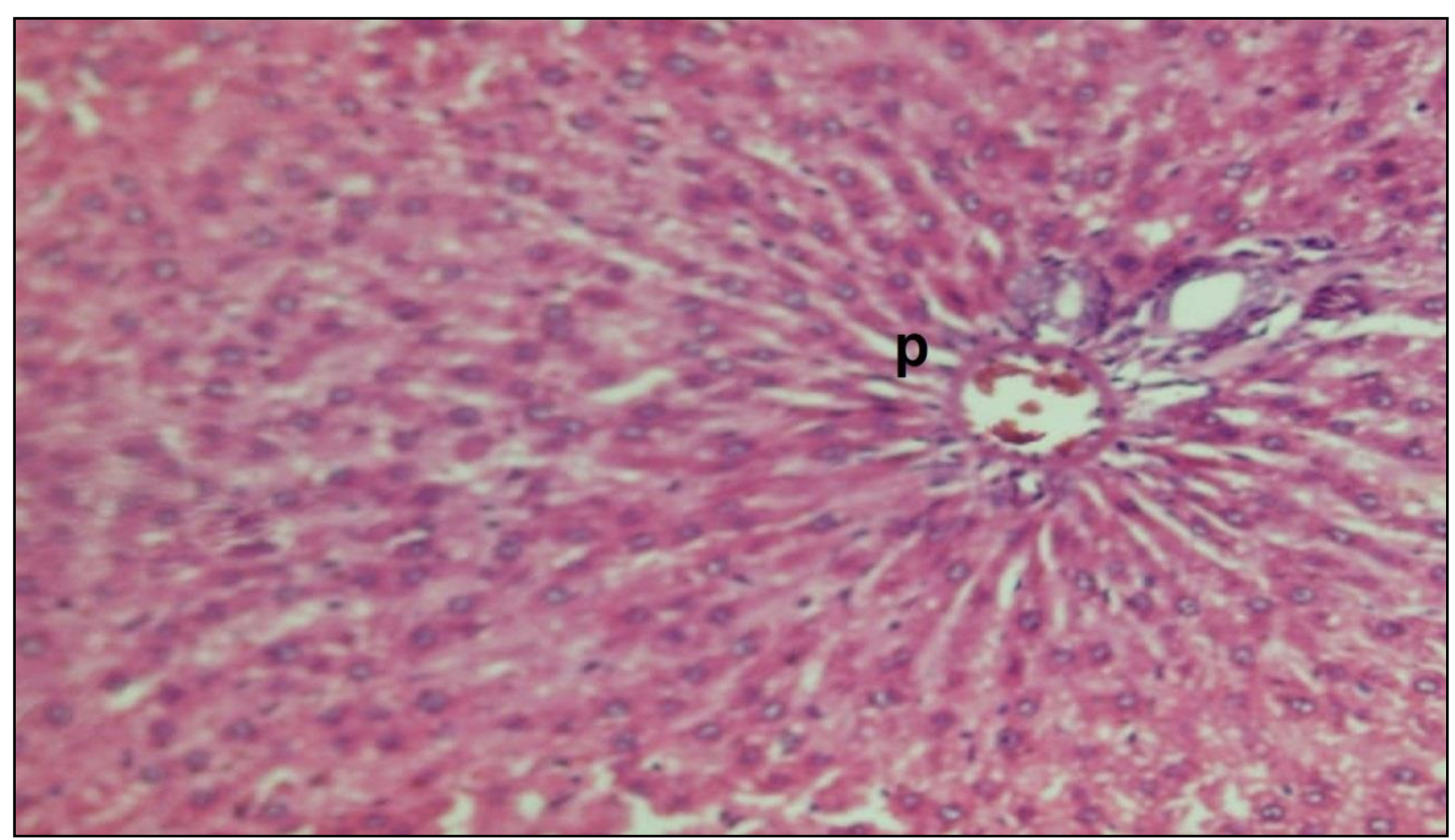

Figure (1): A photomicrograph of liver section of group I showing normal hepatic architecture. Normal hepatocytes. Normal portal areas (P). H\& E staining x200.

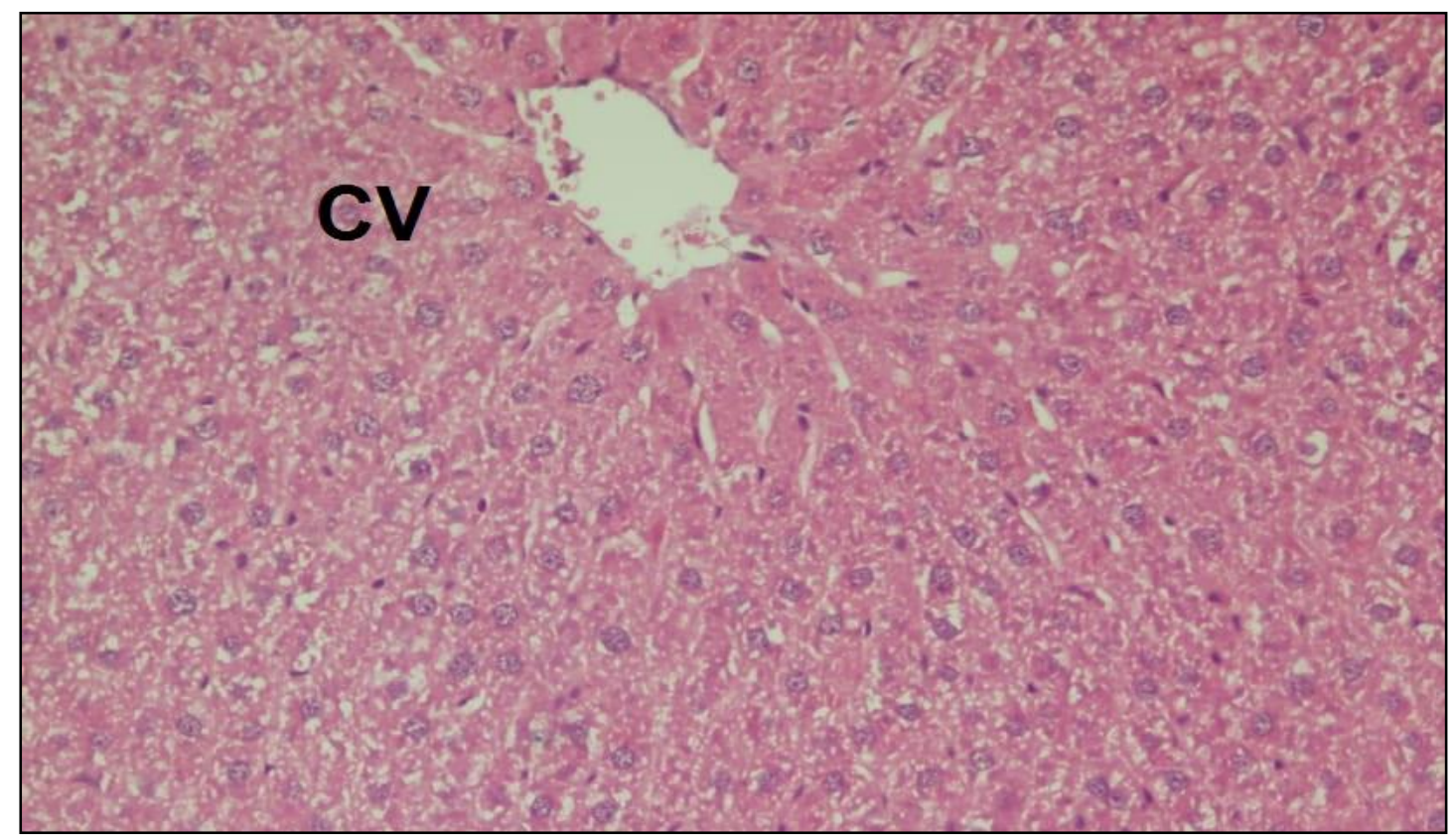

Figure (2): A photomicrograph of liver section of group II showing normal hepatic architecture. Normal central vein (CV) with normal hepatocytes radiating from it. H\& E staining x200. 


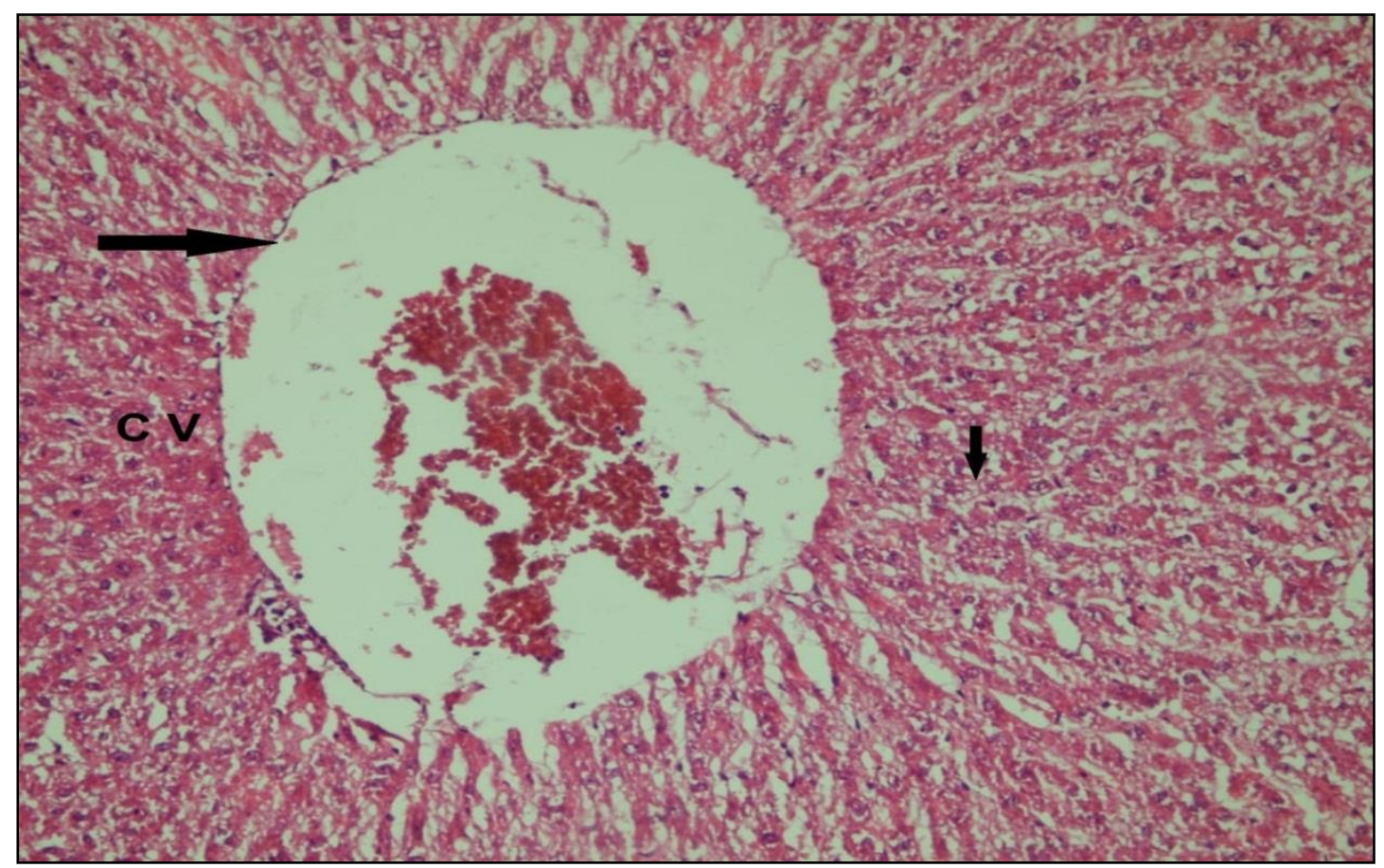

Figure (3): A photomicrograph of a section in the liver of group IIIA showing marked dilated and congested central vein (CV) (horizontal arrow), marked vacuolar degeneration of hepatocytes (vertical arrow). H\&E staining $x 400$.

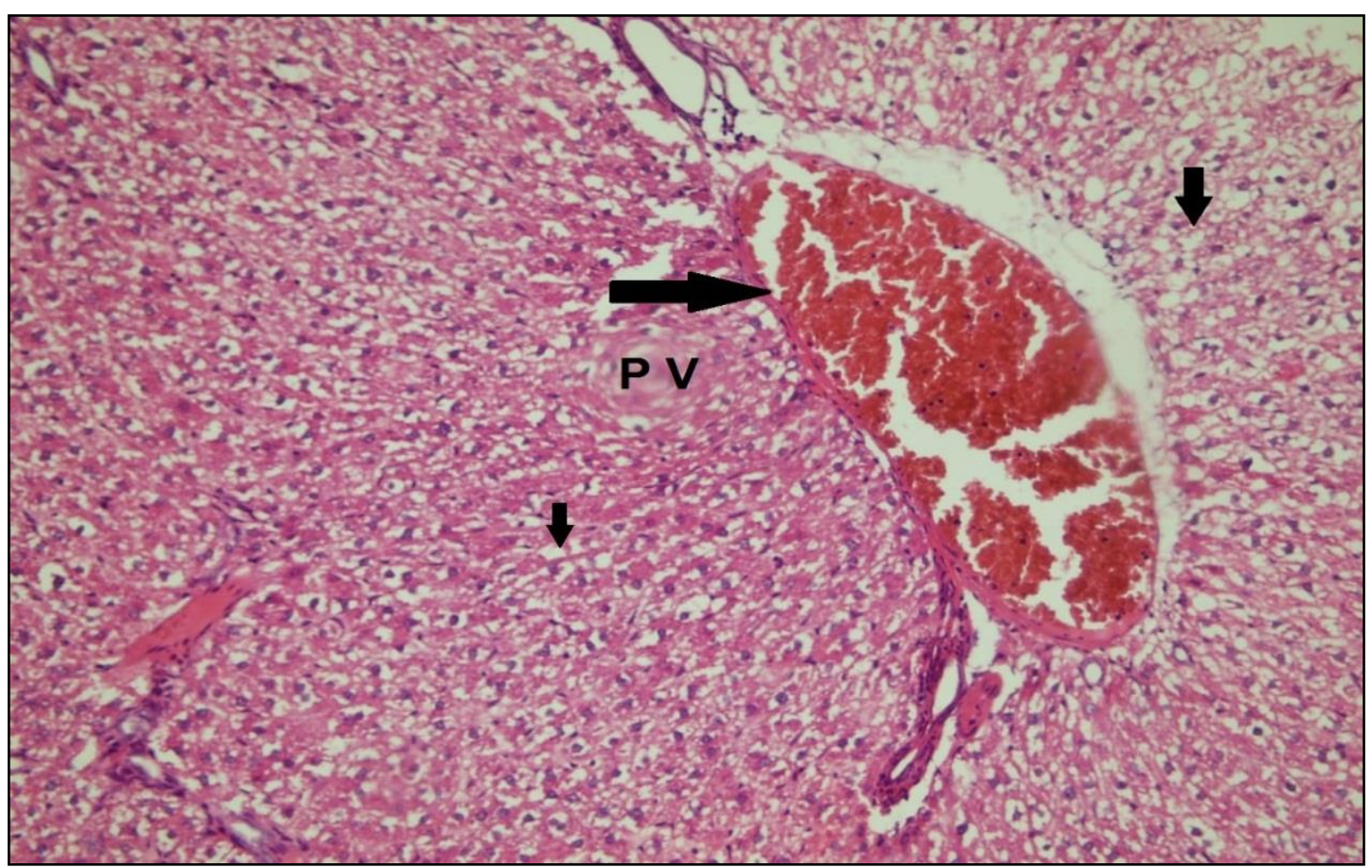

Figure (4): A photomicrograph of a section in the liver of group IIIB showing moderate dilated and congested portal vein (PV) (horizontal arrow), moderate vacuolar degeneration of hepatocytes (vertical arrow). H\&E staining $x 400$. 


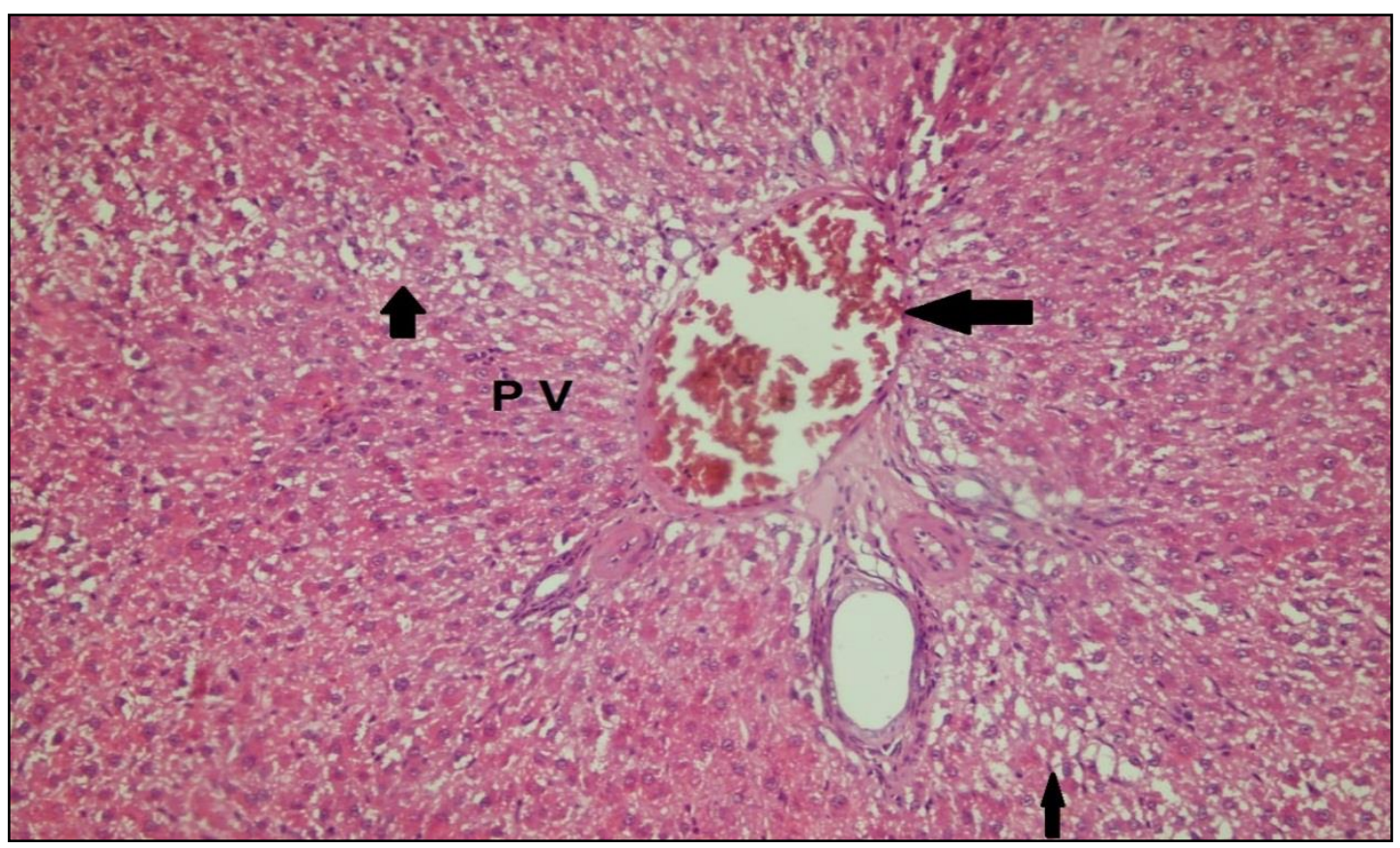

Figure (5): A photomicrograph of a section in the liver of group IVA showing moderate dilated and congested portal vein (PV) (horizontal arrow), moderate vacuolar degeneration of hepatocytes (vertical arrow). H\&E staining x200.

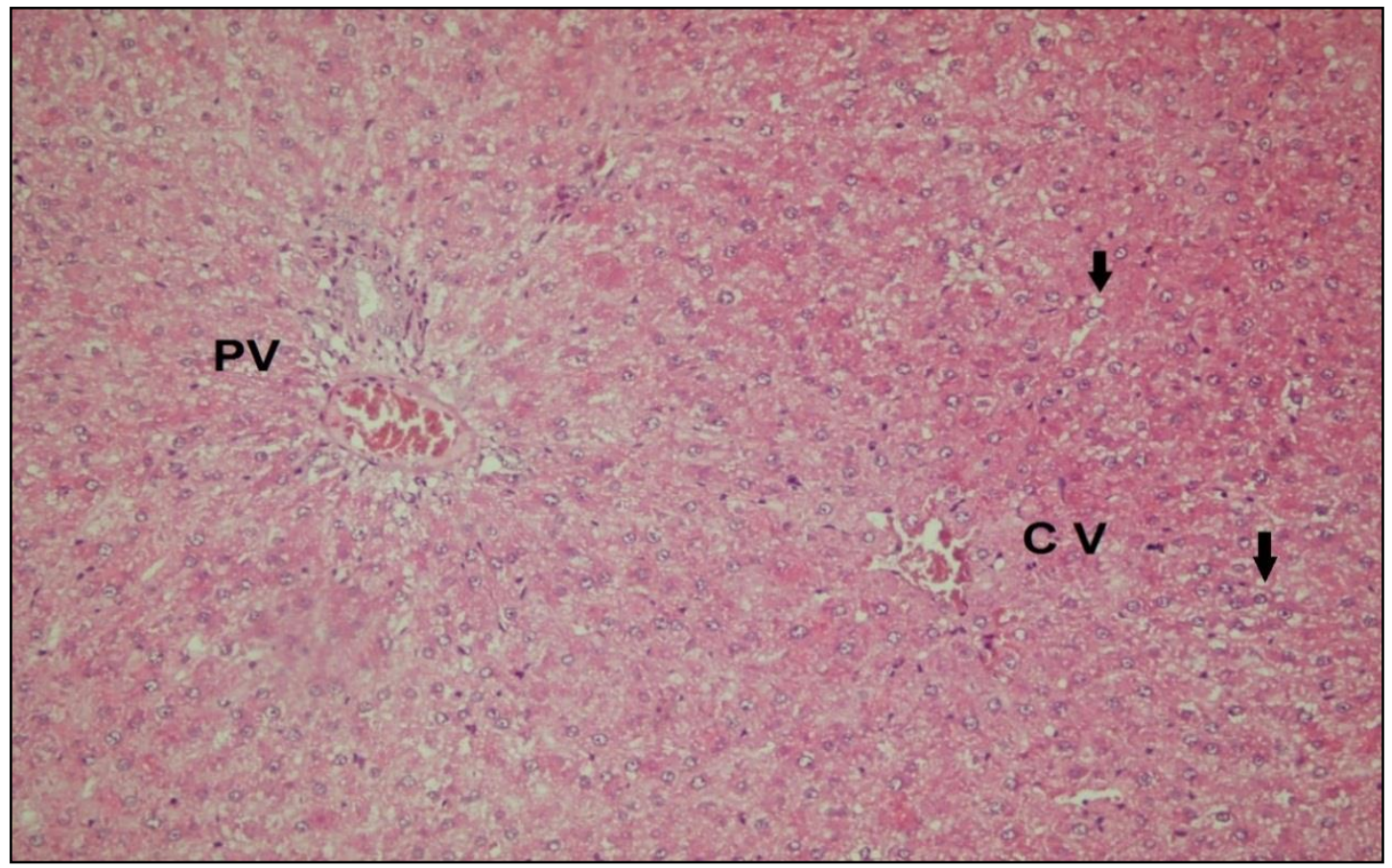

Figure (6): A photomicrograph of a section in the liver of group IVB showing mild dilated and congested portal vein (PV) and central vein (CV), mild vacuolar degeneration of hepatocytes (vertical arrows). H\&E staining $\mathrm{x} 200$. 


\section{Serum ALT (IU/I)}

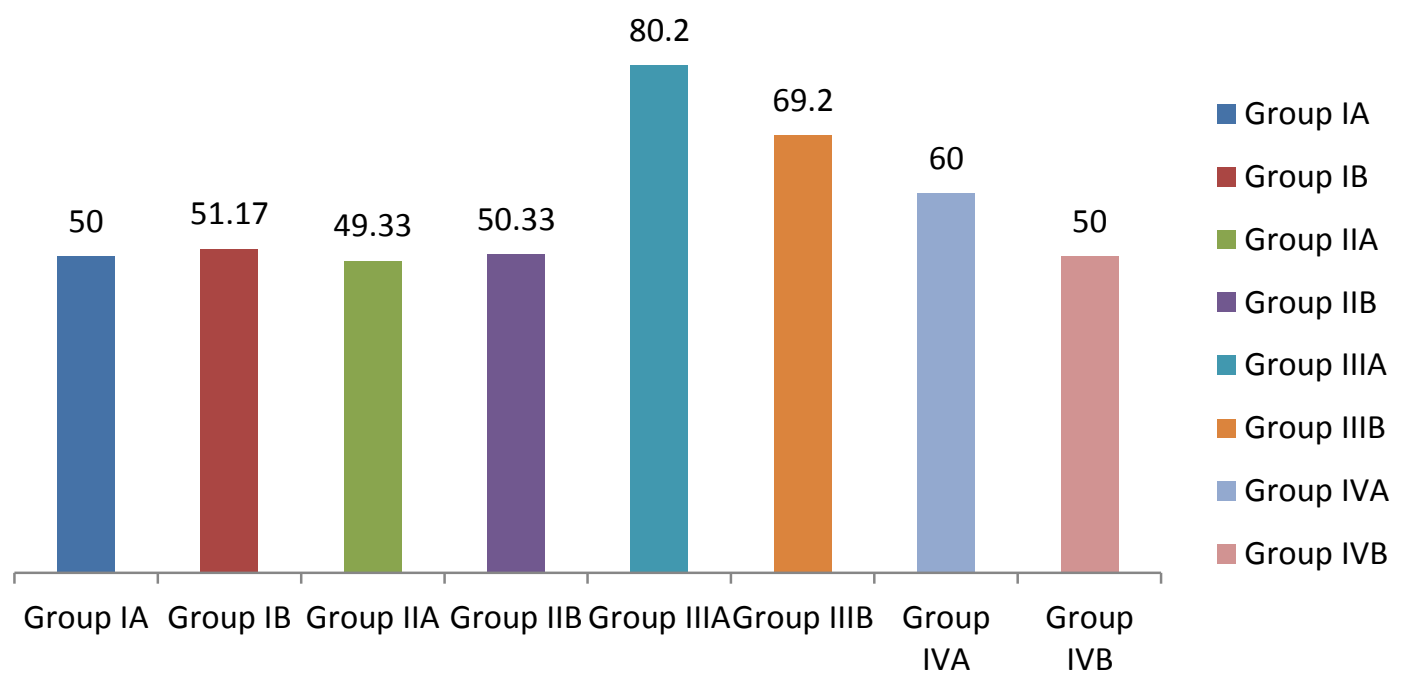

Graph (1): The mean values of serum ALT in the studied groups.

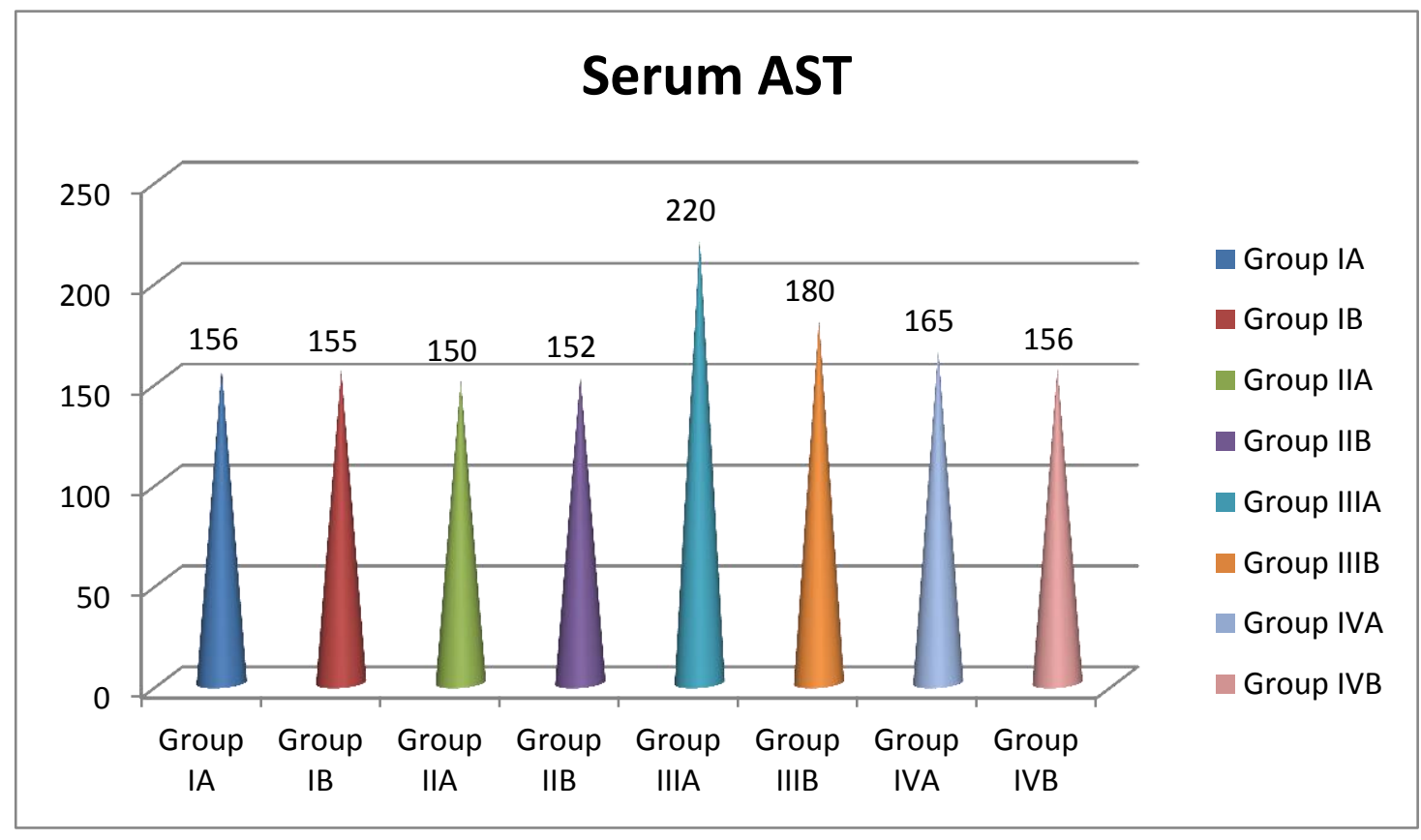

Graph (2): The mean values of serum AST in the studied groups. 


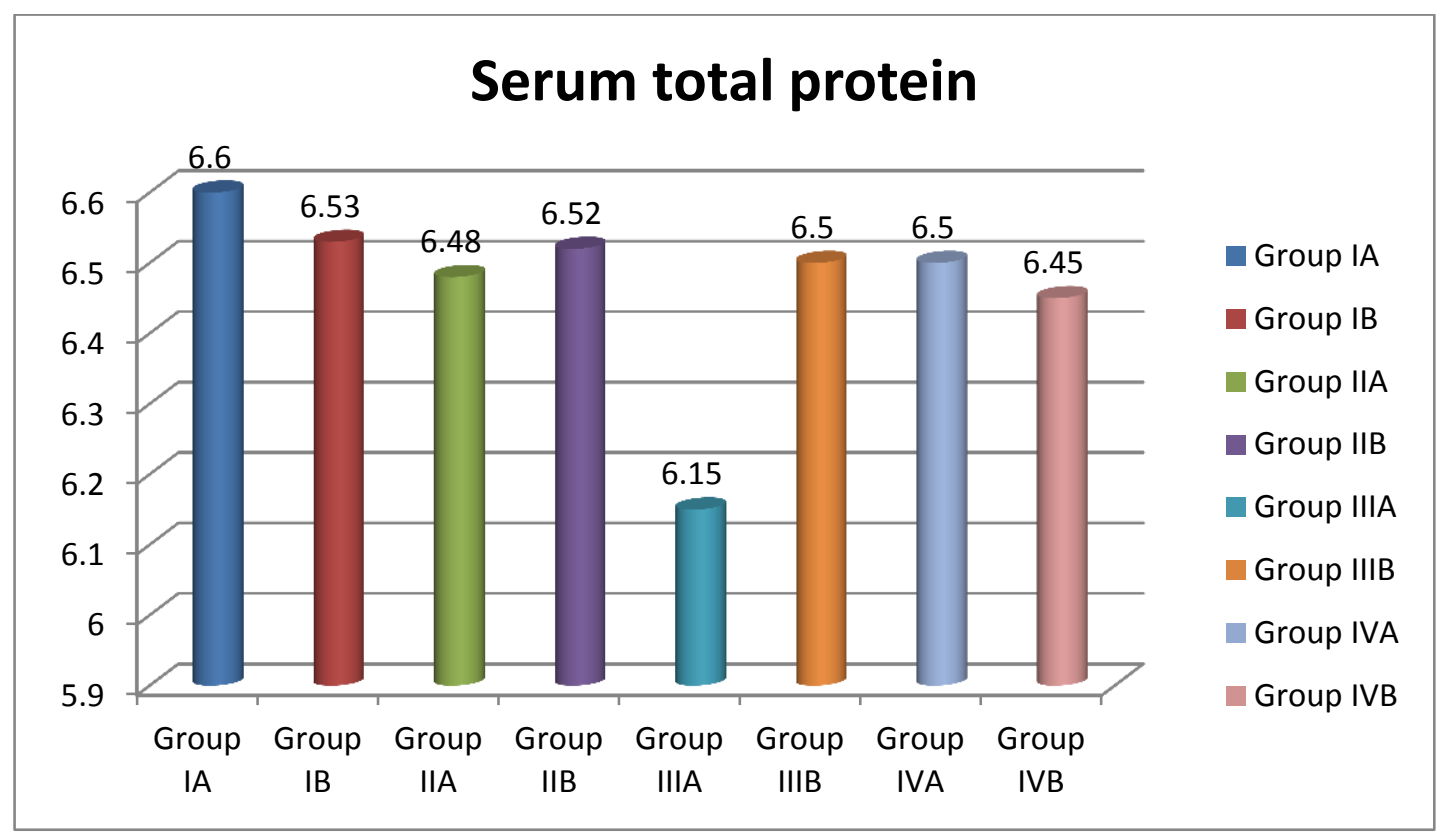

Graph (3): The mean values of serum total protein in the studied groups.

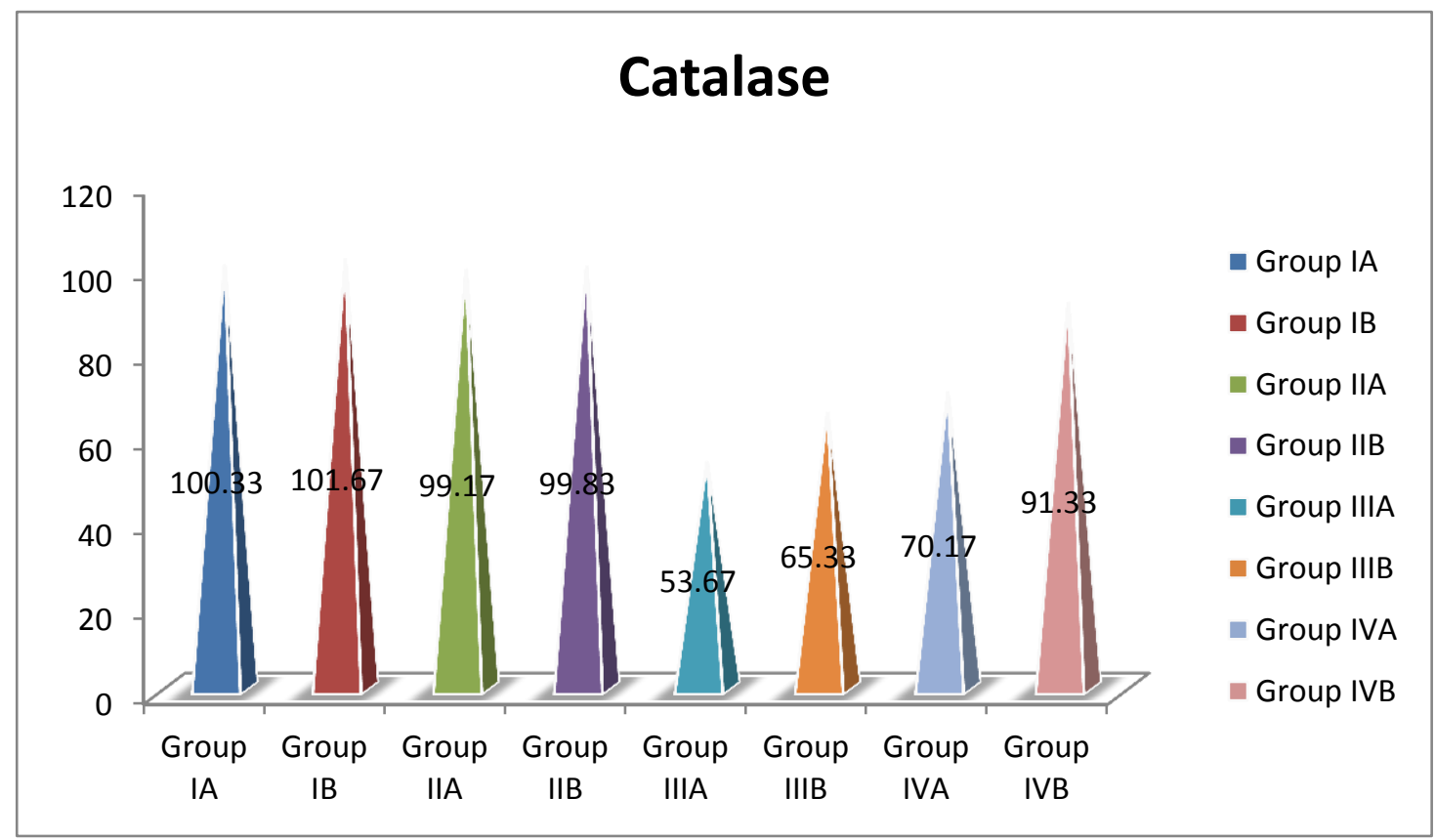

Graph (4: The mean values of serum catalase in the studied groups.

\section{Discussion}

Paracetamol is one of the commonest used drugs and has the advantage of safety if it is used at therapeutic level (Kanno et al., 2006).

Paracetamol over dosage leads to hepatic and renal impairment in humans and animals (Pradhan et al., 2016).

Prime toxicity of paracetamol results from metabolism of the drug in the hepatic and extrahepatic organs (Gu et al., 2005).

ALA is considered as an antioxidant which occurs naturally and it is very important in the process of metabolism (Packer et al., 2001).

The liver is the main and the most important organ for drug detoxification process (Sathish et al., 2012).
After over dosage of paracetamol, it leads to cytochrome $\mathrm{p}_{450}$-dependent liver impairment in human and animals (Bessems and Vermeulen, 2001).

In the evaluation of hepatic injury, the rises of hepatic enzymes (ALT \& AST) commonly used as a markers for hepatocellular necrosis. So, the serum levels of these enzymes are used as quantitative markers of the type and the degree of injury in hepatic cells (Ferah et al., 2013).

In the current study, there was a significant statistical increase in the mean values of serum ALT and AST in group IIIA and group IVA as compared to the control groups. 
This means that the serum levels of ALT and AST in animal groups that ingested toxic dose of paracetamol with or without ALA, was higher than normal.

Co-administration of ALA with toxic dose of paracetamol could not prevent the increase of serum level of ALT and AST, but the rise was less severe.

Toxic dose of paracetamol leads to consumption of the stored glutathione (GSH) and sulfate. This convert excess level of paracetamol to the $\mathrm{CYP}_{-450}$ oxidase system, which will lead to formation of more reactive intermediate (NAPQI), that will make bonds to protein macromolecules intracellularly leading to hepatic cells injury (Bessems and Vermeulen, 2001).

This mechanism leads to initiation of programmed cell death (apoptosis), which leads to hepatic necrosis and dysfunction in the form of elevation of ALT and AST (Lorz et al., 2005).

There were significant statistical decreases in the mean values of serum ALT, AST in the group IIIB as compared to the group IIIA. This means that improvement in liver biochemistry occurred after a period of recovery for 4 weeks following ingestion of toxic dose of paracetamol, despite that it did not return to normal values as control groups.

While in group IVB, treatment with ALA for 4 weeks after stoppage of paracetamol showed improvement of serum level of ALT and AST up to return to normal level as control.

The results of present study were in accordance with Kanchana and Sadiq (2011) who stated that oral ingestion of $400 \mathrm{mg} / \mathrm{kg}$ paracetamol dose in albino rats for a week resulted in increase the serum level of AST, ALT.

Additionally, Abdel-Azeem et al. (2013) recorded that acute toxicity with paracetamol $(600 \mathrm{mg} / \mathrm{kg}$, intraperitoneally) produced noticeable increase in ALT, AST plasma activities in rats.

Analogous findings were recorded by Abdel-Zaher et al. (2008) who mentioned that liver enzymes level improved when paracetamol was orally administered with a dose $750 \mathrm{mg} \backslash \mathrm{kg}$ and ALA with a dose $25 \mathrm{mg} \backslash \mathrm{kg}$ for one week.

The current findings were in harmony with Pradhan et al. (2016), who noticed improvement in hepatic enzymes with concurrent administration of ALA at dose of 50, $100 \mathrm{mg} \backslash \mathrm{kg}$ with a toxic dose of paracetamol $500 \mathrm{mg} \backslash \mathrm{kg}$ I.P for 20 days.

Those results were in agreement with $\mathrm{Al}$ Rasheed et al. (2017) who recorded that administration of paracetamol (single oral dose $750 \mathrm{mg} / \mathrm{kg}$ ) produce rise of hepatic enzymes while treatment with ALA 200 $\mathrm{mg} / \mathrm{kg}$ alleviate the disturbed enzyme levels.

Opposite results were recorded by Elshazly et al. (2014) who recorded that co-ingestion of ALA in a dose of $100 \mathrm{mg} / \mathrm{kg}$ did not improve the rise of ALT serum level caused by overdose of paracetamol $(1.5 \mathrm{~g} / \mathrm{kg}$ i.p. single dose). They recorded that ingestion of $100 \mathrm{mg} / \mathrm{kg}$ of ALA to albino rats lead to slight rise of the ALT enzyme and it was associated with histopathological abnormalities.
Moini et al. (2002b) reported that ALA administration leads to increases glutathione only after 24 hours, which explain the results of Elshazly et al. (2014) as he sacrificed rat after 12 hours of ALA administration.

In the current study, there was a significant statistical decrease in total protein serum level induced by toxic dose of paracetamol which did not occur when paracetamol was co-administered with ALA. The decline in serum total protein improved after a weeks recovery.

The present findings were in accordance with Abdel-Azeem et al. (2013) who reported that acute intoxication with paracetamol $(600 \mathrm{mg} / \mathrm{kg}$, i.p) induced significant decrease in total protein and albumin plasma level.

In accordance with the current study, Lebda et al. (2013) recorded that ingestion of paracetamol to rats at dose of $1 \mathrm{gm} / \mathrm{kg}$ for 21 days leads to significant lowering of serum albumin and total protein levels.

The decrease of total protein serum level may occurs due to decrease number of functional hepatocytes or due to nephrotoxicity which leads to leakage of albumin in urine with decreasing of albumin and total protein serum concentration (Sharma and Rathore, 2011).

Oxidative stress is believed to have a great role in hepatotoxicity. When the equilibrium between the created reactive oxygen species (superoxide anions, hydrogen peroxide and hydroxyl radicals) and antioxidants is disturbed, the free radicals react with macromolecules leading to disruption of cell functions (Birben et al., 2012).

Lipid peroxidation and reduced antioxidant enzymes are principle mechanisms in paracetamolinduced hepatotoxicity (Hinson et al., 2004).

There are three mechanisms suggested to explain elevated ROS level:

Uncoupling of CYP 2E1 or other enzymes, activated NADPH oxidase, and mitochondrial uncoupling (Di Meo et al., 2016).

It has been confirmed that superoxide anion and hydrogen peroxide $\left(\mathrm{H}_{2} \mathrm{O}_{2}\right)$ are formed during metabolic paracetamol activation in the $\mathrm{CYP}_{450}$ system and from the mitochondria during toxicity with paracetamol (Hamza and AL-Harbi, 2015).

The production of superoxide stimulates peroxynitrite formation and protein nitration which lead to oxidative injury to DNA, proteins and lipids (Al-Harbi et al., 2014).

CAT is one of the most essential enzymes which enhance oxygen metabolism (El-Sokkary et al., 2003).

Catalase is suppressed by extra superoxide radical and lipid peroxides (El-Megharbel et al., 2014) and (AL-Harbi, 2015).

The current study has shown that toxicity of paracetamol resulted in significant decline in catalase (CAT) activity as compared to control group.

There was an ameliorative role of ALA when co-administered with toxic dose of paracetamol (Group 
IVA). Better results were achieved when ALA was administered after stoppage of paracetamol (Group IVB).

ALA is distinctive in its capability to behave as an antioxidant in aqueous phases of the cell and lipids (Moini et al., 2002a).

There are four different antioxidant characters of ALA and its reduced form (Palaniyappan and Alphonse, 2011):

- It can bind to transition metals in a chelating manner so inhibit the development of hydroxyl radical.

- It can scavenge ROS

- Its can stimulate endogenous antioxidants as GSH and vitamin $\mathrm{C} \& \mathrm{E}$.

- Lastly, it can restore oxidatively injured proteins, as alpha- 1 antiprotease.

The obtained findings are reinforced by Yousef et al. (2010) who stated that administration of paracetamol (650 mg/kg orally for 15 days) produced significant lowering of antioxidant enzyme; CAT in rat plasma.

Similar results were obtained by Abdel-Zaher et al. (2008). They revealed that ALA has a protective effect by counteracting paracetamol-induced lipid peroxidation and exhaustion of intracellular glutathione.

Our findings agree with those of Elshazly et al. (2014) who stated that ALA at the low dose (20mg/kg) with paracetamol toxic dose (1.5g/kg i.p. single dose) exerted protective actions, where ALA significantly reestablished the alterations of GSH and MDA.

The current findings were in harmony with Pradhan et al. (2016) who stated that paracetamol overdose (500 $\mathrm{mg} \backslash \mathrm{kg}$ ip for ten days) led to a significant decline in the CAT level in plasma. This improved when ALA was co-administered at two dissimilar doses (50-100 mg $\backslash \mathrm{kg})$,

Scott et al. (1994) and Çakatay (2006) recorded that excess ALA and dihydro-lipoic acid (DHLA) may display pro-oxidant effect by iron reducing and producing reactive, sulfur-containing, radicals leading to protein injury.

Çakatay (2006) stated that the pro-oxidant effect is affected by the model of oxidant stress and the body's physiological status.

Also, the different findings could be explained that when large amounts of ALA react with oxygen in the mitochondria, forming superoxide anions which interact with the double bonds in unsaturated lipids within mitochondrial membranes, leading to lipid oxidation.

Thus, moderate doses intake of ALA has protective effect, while larger doses or i.p ALA cause oxidative stress (Shay et al., 2009).

The main organ for paracetamol toxicity thought to be the liver as it is the primary site at which the detoxification of the drug takes place (Hewawasam et al., 2003).

In the current study, ALA induced no pathological changes in liver architecture, while paracetamol induced marked dilatation and central vein congestion and congestion of the portal venules, marked hepatocytic vacuolar degeneration. These changes became less severe after period of recovery.

Co-administration of ALA with toxic dose of paracetamol led to changes of central vein and portal venules in the form of moderate dilatation and congestion and moderate hepatocytic vacuolar degeneration. Less damage was observed when ALA was administered as treatment for 4 weeks following toxicity and stoppage of paracetamol, in the form of mild congestion and dilatation of central vein and portal venules, mild hepatocytic vacuolar degeneration.

There are two predominant theories for paracetamol to cause cell death:

1. First one is the theory of oxidative stress where paracetamol metabolites induce oxidative stress in the target cell which leads to its death. Lipid peroxidation which is generated by ROS is thought to be a major cause of disruption to cell membranes (Zhao et al., 2011).

2. The other one is the theory of covalent binding where highly reactive metabolites of paracetamol bound to cellular macromolecules causing death of the cell (Anoush et al., 2009).

The main finding recorded in paracetamol toxicity is liver centrilobular necrosis.

The explanation for that finding could be that the central zone liver cells are rich in CYP2E1, so they are most susceptible to injury by paracetamol toxicity (Hodgman and Garrard, 2012).

These findings were in accordance with AbdelZaher et al. (2008) results. Where there was marked vacuolar degeneration and moderate centrilobular necrosis in liver histopathological examination following ingestion of paracetamol $750 \mathrm{mg} \backslash \mathrm{kg}$ for one week. While no abnormal finding was observed when ALA was co-administered for the same duration.

The present study findings were agreed by Mahmoud et al. (2015). They noticed centrilobular necrosis, vacuolar degeneration in a moderate manner and infiltration of inflammatory cell in liver microscopic examination when paracetamol was administered to the rats with a dose of $3 \mathrm{~g} / \mathrm{kg}$ orally (acute overdose). This effect improved partially when ALA was administered as $100 \mathrm{mg} / \mathrm{kg}$ before toxic dosage of paracetamol.

The current results were in a harmony with Pradhan et al. (2016), who stated that severe disturbance of hepatocytes was detected when paracetamol given parenterally with a dose of $500 \mathrm{mg} / \mathrm{kg}$ for ten days. After administration of ALA with the dosage of 50 and $100 \mathrm{mg} / \mathrm{kg} /$ day for twenty days, there were normal liver cells as well as mild affected cells with a minimal disorganization.

\section{Conclusion}

Repeated oral administration of paracetamol affects liver both functionally and pathologically. Also, oxidative stress has occurred in the form of increased catalase level. ALA has the ability to protect against the above mentioned effects. The protective effects increased when ALA was administered for another 4 weeks after stoppage of paracetamol. 


\section{Recommendations}

- It is advisable to restrict prolonged use of paracetamol to avoid its hepatotoxic and oxidative stress effects.

- It is recommended that physicians prescribe alpha lipoic acid when prolonged use of paracetamol is indicated as in cases of osteoarthritis or cancer pain even after stoppage of paracetamol administration.

\section{References}

Abdel-Azeem, A.S.; Hegazy, A.M.; Ibrahim, K.S.; Farrag, A.R. and El-Sayed, E.M. (2013): Hepatoprotective, antioxidant and ameliorative effects of ginger (Zingiber officinale Roscoe) and vitamin E in acetaminophen treated rats. J. Diet. Suppl., 10(3):p.195-209.

Abdel-Zaher, A.O.; Abdel-Hady, R.H.; Mahmoud, M.M. and Farrag, M.Y (2008): The potential protective role of alpha-lipoic acid against acetaminophen-induced hepatic and renal damage. Toxicology, 243:p. 261-270.

Al-Harbi, M.S.; Hamza, R.Z. and Al-Sofiani, T.A. (2015): Ameliorative roles of silymarin and Nigella sativa on hematological parameters and immunological capacities of male mice affected by paracetamol. Biosci. Biotechnol. Res. Asia, 12(1):p. 379-385.

Al-Harbi, M.S.; Hamza, R.Z. and Dwary, A.A. (2014): Ameliorative effect of selenium and curcumin on sodium fluoride induced hepatotoxicity and oxidative stress in male mice. J. Chem. Pharm. Res., 6:p. 984-998.

Al-Rasheed, N. M.; Fadda, L.; Al-Rasheed, N. M.; Hasan. I. H.; Ali, H. M.and Al-Fayez, M. (2017): Hepatoprotective role of $\alpha$-lipoic acid and thymoquinone in acetaminophen- induced liver injury: down-regulation of COX-2 and flt1 expression. Braz. Arch. Biol. Technol., 60:p.1-11.

Anoush,M.; Eghbal, M. and Fathiazad,F. (2009): The protective effects of garlic extract against acetaminophen-induced oxidative stress and glutathione depletion. Pak. J. Biol. Sci., 12 (10):p.765-771.

Bessems, J. G .and Vermeulen, N.P. (2001): Paracetamol induced toxicity: molecular and biochemical mechanisms, analogues and protective approaches. Crit. Rev. Toxicol., 31:p. 55-138.

Birben, E.; Sahiner, U.M.; Sackesen, C.; Erzurum, S. and Kalayci, O.(2012): Oxidative Stress and antioxidant defense. World Allergy Organ J., 5: p.9-19.

Boyd, E. M. and Bereczky, G. M. (1966): Liver Necrosis from paracetamol.Brit. J. Pharmacol., 26:p. 606-614.

Çakatay, U. (2006): Pro-oxidant actions of $\alpha$-lipoic acid and dihydrolipoic acid. Med. Hypoth., 66:p. $110-117$.

Daly, F.F.; Fountain, J.S.; Murray, L.; Graudins, A. and Buckley, N.A (2008): Guidelines for the management of paracetamol poisoning in Australia and New Zealand-explanation and elaboration. A consensus statement from clinical toxicologists consulting to the Australasian poisons information centers. Med. J. Aust., 188:p.296-301.

Di Meo, S.; Reed, T. T.; Venditti, P. and Victor, V. M. (2016): Role of ROS and RNS sources in physiological and pathological conditions. Oxid. Med. Cell. Longev., 2016: p. 1-44.

El-Megharbel, S.M.; Hamza, R.Z. and Refat, M.S. (2014): Synthesis, spectroscopic and thermal studies of Mg (II), Ca (II), Sr (II) and Ba (II) diclofenac sodium complexes as antiinflammatory drug and their protective effects on renal functions impairment and oxidative stress. Spectrochim Acta. A. Mol. Biomol. Spectrosc., 135:p. 915-928.

Elshazly, S.; Moselhy, M. and Barakat, W. (2014): Insights in the mechanism underlying the protective effect of $\alpha$-lipoic acid against acetaminophen-epatotoxicity. Eur.J. Pharmacol., 726:p. $116-123$.

El-Sokkary, G.H.; Kamel, E.S. and Reiter, R.J. (2003): Prophylactic effect of melatonin in reducing lead-induced neurotoxicity in the rat. Cell Mol. Biol. Lett., 8:p. 461-470.

Gelotte, C.K.; Auiler, J.F.; Lynch, J.M.; Temple, A.R. and Slattery, J.T. (2007): Disposition of acetaminophen at 4, 6, and $8 \mathrm{~g}$ /day for 3 days in healthy young adults. Clin. Pharmacol.Ther., 81(6):p. 840-848.

Gu, J.; Cui, H.; Behr, M.; Zhang, L.; Zhang, Q.Y.; Yang, W.; Hinson, J.A.and Ding, X. (2005): In vivo mechanisms of tissue selective drug toxicity: effects of liver-specific knockout of the NADPH-cytochrome $\mathrm{P}-450$ reductase gene on acetaminophen toxicity in kidney, lung, and nasal mucosa. Mol. Pharmacol., 67:p.623-630.

Hamza, R.Z. and AL-Harbi, M.S. (2015): Silymarin and Nigella sativa extract ameliorate paracetamol induced oxidative stress and renal dysfunction in male mice. Asian Pac. J. Trop. Dis., 5(1):p. 169-174.

Hewawasam, R.P.; Jayatilaka, K.A.; Pathirana, C. and Mudduwa, L.K. (2003): Protective effect of Asteracantha longifolia extract in mouse liver injury induced by carbon tetra-chloride and paracetamol. J. Pharm. Pharmacol., 55:p.14131418.

Hinson, J.A.; Reid, A.B.; McCullough, S.S. and James, L.P. (2004): Acetaminophen-induced hepatotoxicity: role of metabolic activation, reactive oxygen/nitrogen species, and mitochondrial permeability transition. Drug Metab. Rev., 36(4):p.805-822.

Hodgman, M.J. and Garrard, A.R. (2012): A review of acetaminophen poisoning. Crit. Care Clin., 28:p.499-516.

Jaeschke, H.; Williams, C.D.; Ramachandran, A. and Bajt, M.L. (2012): Acetaminophen hepatotoxicity and repair: the role of sterile inflammation and innate immunity. Liver Int., 32:p. 8-20. 
James, L.P.; Chiew, A.; Abdel-Rahman, S.M.; Letzig, L.; Graudins, A.;Day, P. and Roberts, D. (2013): Acetaminophen protein adduct formation following low-dose acetaminophen exposure: comparison of immediate release vs extended-release formulations. Eur. J. Clin. Pharmacol., 69:p.851-857.

Ji, P.; Wang, Y.; Li, Z.; Doddapaneni, S.; Hertz, S.; Furness, S. And Sahajwalla, C.G. (2012): Regulatory review of acetaminophen clinical pharmacology in young pediatric patients. J. Pharm. Sci., 101:p.4383-4389.

Kanchana, N. and Sadiq, A.M. (2011): Hepatoprotective effect of plumbago zeylanica on paracetamol induced liver toxicity in rats. Int. J. Pharm. Sci., 3(1):p.151-154.

Kanno, S.; Tomizawa, A.; Hiura, T.; Osanai, Y.; Kakuta, M.; Kitajima, Y.;Koiwai, K.; Ohtake, T.; Ujibe, M. and Ishikawa, M. (2006): Melatonin protects on toxicity by acetaminophen but not on pharmacological effects in mice. Biol. Pharm. Bull., 29:p. 472-476.

Karaarslan, U.; İşgüder, R.; Bağ, Ö.; Kışla, M.; Ağın, H.; and Ünal, N.(2013): Alpha lipoic acid intoxication, treatment and outcome. Clin.Toxicol., 51(6):p.522-523.

Kiran, P.M.; Raju, A.V. and Rao, B.G. (2012): Investigation of hepatoprotective activity of Cyathea gigantea (Wall. ex. Hook.) leaves against paracetamol-induced hepatotoxicity in rats. Asi. Pac. J. Trop. Biomed., 2(5):p. 352-356.

Koufaki, M. and Detsi, A. (2010): Design and synthesis of antioxidant $\alpha$ - lipoic acid hybrids. Methods Mol. Biol., 594:p.297-309.

Lebda, M.A.; Nabil, M.T.; Mahdy, A.; Korshom, A.; Abd El-Wahab, A.M.and Raghda, I.G. (2013): Ginger (Zingiber officinale) potentiates paracetamol induced chronic hepatotoxicity in rats. Journal of Medicinal Plants Research, 7(42):p. 3164-3170.

Lorz, C.; Justo, P.; Sanz, A.B.; Egido, J. and Ortíz, A. (2005): Role of BclxL in paracetamol-induced tubular epithelial cell death. Kidney Int., 67:p.592-601.

Mahmoud, Y.; Mahmoud, A. and Nassar, G. (2015): Alpha-lipoic acid treatment of acetaminopheninduced rat liver damage. Biotechnic \& Histochemistry, 90(8):p. 594-600.

McGill, M.R. and Jaeschke, H. (2013): Metabolism and disposition of acetaminophen: recent advances in relation to hepatotoxicity and diagnosis. Pharm. Res., 30:p.2174-2187.

Moini, H.; Packer, L. and Saris, N.E. (2002a): Antioxidant and prooxidant activities of $\mathrm{R}$ lipoic acid and dihydrolipoic acid. Toxicol. Appl. Pharmacol., 182:p.84-90.

Moini, H.; Tirosh, O.; Park, Y.C. and Packer.L. (2002b): R- $\alpha$-lipoic acid action on cell redox status, the insulin receptor, and glucose uptake in 3T3-L1 adipocytes. Arch Biochem. Biophys., 397:p.384-391.

Pachaiyappan, S.V. Deecaraman, M.; Vijayalakshmi, M. and Sakthivelan,S.M.(2014): Sub-acute toxicity studies of acetaminophen in sprague dawley rats. Biological Pharmaceutical Bulletin, 37(7):p. 1184-1190.

Packer, L.; Kraemer, K. and Rimbach, G. (2001): Molecular aspects of lipoic acid in the prevention of diabetes complications. Nutrition, 17:p.888-895.

Palaniyappan, A. and Alphonse, R. (2011): Immunomodulatory effect of DL- $\alpha$-lipoic acid in aged rats. Exp. Gerontol., 46:p.709-715.

Pradhan, S.; Roy, S.; Mandal, S.; Das, K.; Sukhen, D.; and Kumar, N.(2016): Protective effect of alpha lipoic acid on hepatorenal toxicity on acetaminophen induced uremic male albino rat. European Journal of Biomedical and Pharmaceutical sciences,

Sathish, R.; Anbu, J.; Murgesan, M.; Ashwini, A. and Arun, K. (2012):Toxicity study on siddha formulation mega sajeevi mathirai in albino rats. Int. J. Pharm. Bio. Sci., (3):p. 121-130.

Scott, B.C.; Aruoma, O.I.; Evans, P.J.; O’Neill, C.; Van der Vliet, A.;Cross, C.E.; Tritschler, H. and Halliwell, B. (1994): Lipoic and dihydrolipoic acids as antioxidants: A critical evaluation. Free Radic. Res., 20:p.119-133.

Sharma, A. and Rathore, H.S. (2011): Prevention of acetaminophen induced hepatorenal damage in mice with rhizomes of Glycyrriza Glabra: A Histological study. Anc. Sci. Life, 30(3):p. 7277.

Shay, K.P.; Moreau, R.F.; Smith, E.J.; Smith, A.R. and Tory, M.H. (2009): Alpha-lipoic acid as a dietary supplement: molecular mechanisms and therapeutic potential. Biochim. Biophys. Acta., (10):p.1149-1160.

Swierkosz, T.A.; Jordan, L.; Mcbride, M.; Mcgough, K.; Devlin, J. And Botting, R.M. (2002): Actions of paracetamol on cyclooxygenases in tissue and cell homogenates of mouse and rabbit. Med. Sci. Monit.,8 (12):p.496-503.

Vigil, M.; Berkson, B.M. and Garcia, A.P. (2014): Adverse effects of high doses of intravenous alpha lipoic acid on liver mitochondria. Glob. Adv. Health Med., 3:p.25 - 27.

Wada, H.; Shintani, D. and Ohlrogge, J. (1997): Why do mitochondria synthesize fatty acids? Evidence for involvement in lipoic acid production. Proc. Natl. Acad. Sci. U.S.A., 94(4):p.1591-1596.

Yousef, M.I.; Omar, S.A.; El-Guendi, M.I. and Abdelmegid, L.A. (2010): Potential protective effects of quercetin and curcumin on paracetamol induced histological changes, oxidative stress, impaired liver and kidney functions and haematotoxicity in rat. Food Chem.Toxicol., 48:p. 3246-3261.

Zhao, Y.L.; Zhou, G.D.; Yang, H.B.; Wang J.B.; Shan, L.M.; Li, R.S.and Xiao, X.H. (2011): Rhein protects against acetaminophen-induced hepatic and renal toxicity. Food Chem. Toxicol., 49(8):p.1705-1710. 


\section{دراسة تجريبية للتأثير الوقائي المحتمل لحمض ألفا ليبويك على الإجهاد التأكسدي الناجم عن الباراسيتامول والسمية الكبلية في الفئران البيضاء الإناء التياء}

ولاء اهمد علام'، و سارة السيد قاسم'، و شرين فراج عمود" ، و أماني عباس عبد اللّ"، و مها عبدالحميدهلال'

الملخص العربي

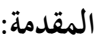

الباراسيتامول، هو دواء مسكن وخافض للحرارة يستخدم على نطاق واسع في العالم، وليس له تأثيرات سلبية/ في

الجر عات العلاجية. ولكن في الجرعات العالية ينسبب في تلف الكبد والإجهاد التأكسدي.

الهـف من الاراسة:

تم تصميم الدراسة الحالية للتحقيق في الثأثيرات السامة للبار اسيتامول على الكبد والإجهاد التأكسدي بعد جرعة فموية

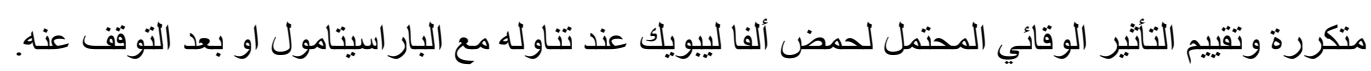

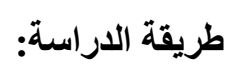

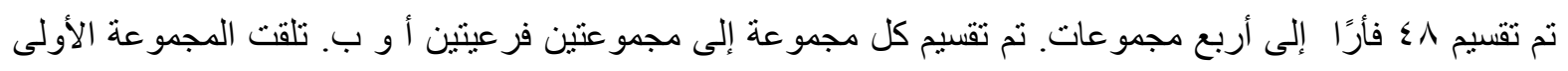

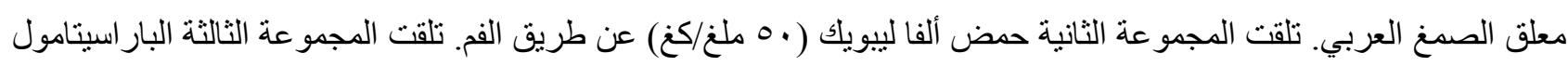

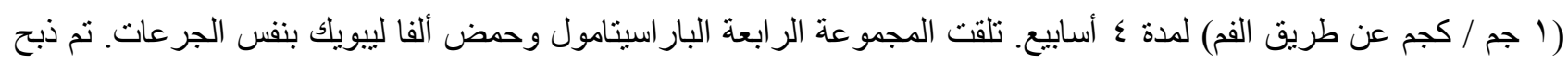

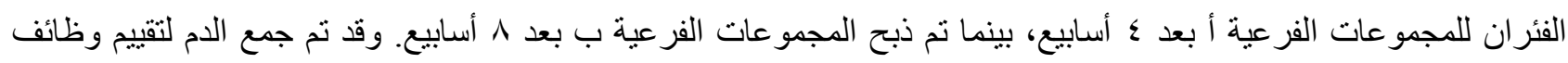
الكبد و علامة الإجهاد التاكسدي. تم الحفاظ على الكبد لفحوصات الأنسجة.

النتائج:

أثتنت الدراسة أن الإعطاء المنكرر للبار اسيتامول يسبب اختلال في وظائف الكبد ويسبب ايضا الإجهاد التأكسدي. لكن

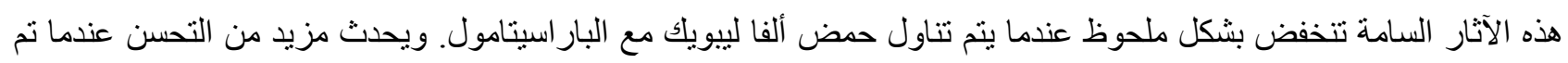
إعطاء ALA لمدة ؛ أسابيع أخرى بعد توقف البار اسيتامول.

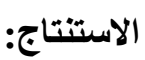

خلصت الدراسة الحالية إلى أن إعطاء البار اسيتامول الهنكرر له نأثير الإجهاد السام للكبد والأكسدة وأن حمض ألفا لييويك له تأثير وقائي ضد هذه الآثار الضارة خاصة عندما تم إعطاء ALA لمدة ؛ أسابيع أخرى بعد توقف البار اسيتامول. 